Corruption as an Empty Signifier 


\section{Africa-Europe Group for Interdisciplinary Studies}

Series Editors

Gregor Dobler, University of Freiburg, Germany Elísio Macamo, Basel University, Switzerland

\section{Editorial Board}

William Beinart, University of Oxford, UK Filip De Boeck, Catholic University Leuven, Belgium Patrick Chabal, King's College London, UK

Paul Nugent, Edinburgh University, UK Nic van de Walle, Cornell University, Ithaca, USA

VOLUME 10

The titles published in this series are listed at brill.com/agis 


\title{
Corruption as an Empty Signifier
}

\author{
Politics and Political Order in Africa
}

\author{
By \\ Lucy Koechlin
}

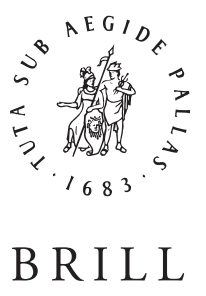

LEIDEN • BOSTON

2013 
This is an open access title distributed under the terms of the prevailing

CG-BY-NC License at the time of publication, which permits any non-commercial use, distribution, and reproduction in any medium, provided the original author(s) and source are credited.

RII

An electronic version of this book is freely available, thanks to the support of libraries working with Knowledge Unlatched $(\mathrm{KU})$. KU is a collaborative initiative designed to make high quality content Open Access for the public good. More information about the initiative and links to the Open Access version can be found at www.knowledgeunlatched.org.

Cover illustration: Wooden scaffolding around new building in Dar es Salaam. @iStockphoto.com/ LanceB

Library of Congress Cataloging-in-Publication Data

Koechlin, Lucy.

Corruption as an empty signifier : politics and political order in Africa / by Lucy Koechlin. p. cm. - (Africa-Europe Group for Interdisciplinary Studies ; v. 10)

Includes bibliographical references and index.

ISBN 978-90-04-24999-8 (pbk. : alk. paper) — ISBN 978-90-04-25298-1 (e-book) 1. Political corruption-Africa. 2. Africa-Politics and government-1960-3. Democratization-Africa. I. Title. II. Series: African-Europe Group for Interdisciplinary Studies (Series) ; v. 10.

DT30.5.K644 2013

364.1323096 - dc23

2013011077

This publication has been typeset in the multilingual "Brill" typeface. With over 5,100 characters covering Latin, IPA, Greek, and Cyrillic, this typeface is especially suitable for use in the humanities. For more information, please see www.brill.com/brill-typeface.

ISSN 1574-6925

ISBN 978-90-04-24999-8 (paperback)

ISBN 978-90-04-25298-1 (e-book)

Copyright 2013 by Koninklijke Brill NV, Leiden, The Netherlands.

Koninklijke Brill NV incorporates the imprints Brill, Global Oriental, Hotei Publishing, IDC Publishers and Martinus Nijhoff Publishers.

All rights reserved. No part of this publication may be reproduced, translated, stored in a retrieval system, or transmitted in any form or by any means, electronic, mechanical, photocopying, recording or otherwise, without prior written permission from the publisher.

Authorization to photocopy items for internal or personal use is granted by Koninklijke Brill NV provided that the appropriate fees are paid directly to The Copyright Clearance Center, 222 Rosewood Drive, Suite 910, Danvers, MA 01923, USA.

Fees are subject to change.

This book is printed on acid-free paper. 


\section{CONTENTS}

List of Figures, Tables and Boxes .............................................................. v vii

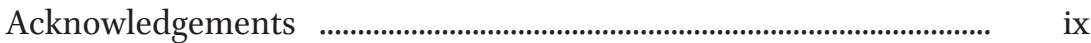

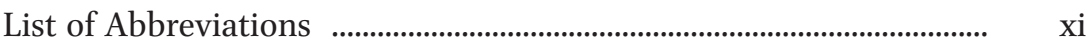

Introduction Corruption, Politics and Africa $\quad$...................................... 1

1. 'Corruption ruins lives: take action!' ........................................... 1

2. Development Discourse: Good Governance and the 'Anti-Corruption Machine' ........................................................ 5

3. 'Rational', 'Rotten' or 'Routine': What is Corruption? ............. 13

4. Discourses of Corruption, Discourses of Africa ........................ 18

5. Methodology and Organisation of the Enquiry …………….... 21

1 The Academic Discourse: Political Order and Corruption in

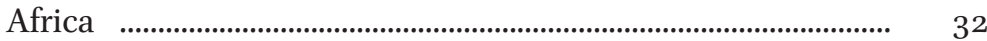

1. Introduction ………………………………………………….... 32

2. Corruption and Political Development: Assimilation and Integration .................................................................................. 37

3. The Political Economy of Corruption: Rules and Regimes ... 49

4. The Moral Economy of Corruption: Values and Practices .... 62

5. The Order of Disorder: Power, Authority and Accumulation ................................................................................. 68

6. Conceptualising Corruption: The Question of Agency .......... 79

7. Conclusions: Corruption, (Dis) Order and Agency .................... 87

2 Sketching Out an Emancipatory Discourse: Corruption, Political Spaces and Social Imaginaries .................................... 91

1. Introduction .................................................................................. 91

2. Reinserting Politics: A Political Theory of Corruption ........... 95

3. Civil Society: The Omni-Present Absence in Africa ............... 104

4. The State of the Economy ……………………………................ 114

5. Organized Business Interests ...................................................... 121

6. Professional Associations in Africa ........................................... 125

7. The Politics of Corruption ……………………………………...... 128

Interlude A Topography of Corruption in Tanzania $\quad$........................ 132

1. Why a Topography? ...................................................................... 133 
2. A Bird's Eye View: Development, Governance and

Corruption in Tanzania

3. Qualified Views of Corruption in Tanzania

4. An Overview over Corruption in Tanzania

3 Democratic Spaces in the Making? Professional Associations and Corruption in 2003

1. Background: From the 'Politics of Integrity' (Julius Nyerere 1962-1985) to the 'Politics of Shamelessness' (Ali Hassan Mwinyi 1985-1995)

2. Benjamin Mkapa (1995-2005) —'Zero-Tolerance of Corruption' 166

3. Regulatory Framework and Anti-Corruption Institutions .... 169

4. Governance Policies in the Construction Industry 178

5. Corruption and Professional Associations in the Tanzanian Construction Industry

6. Hegemonies and Fixations of Corruption: Some Preliminary Conclusions 200

4 Closures of Democratic Spaces? Professional Associations and Corruption in 2010

1. Introduction

2. Jakaya Kikwete-'A dedicated spirit of government'? 205

3. Governance and Anti-Corruption Reforms in the Regulatory Framework

4. Governance Reforms in the Construction Industry 214

5. Professional Associations and Corruption in the

Construction Industry

6. 'Our voice is not heard': Perspectives on Public Officials 226

7. Hegemonies and Fixations of Corruption: Conclusions in Space and Time

Conclusions Corruption, Politics and Political Order

1. Corruption, Development and Political Order

2. Reassessing the Academic Discourse on Corruption in Africa

3. The Politics of Corruption as an Empty Signifier

4. Corruption, Identity and Democratic Politics 


\section{LIST OF FIGURES, TABLES AND BOXES}

\section{Figures}

1. A Timeline of Anti-Corruption Conventions ……………………...... 4

2. A Timeline of Governance and Corruption Indices ………............. 9

3. World Map of Corruption 2009 .......................................................... 15

4. World Governance Index (Tanzania) 1998-2008 ............................ 141

5. Personal Experience of Corruption 2003-2005 …………………... $\quad 15^{2}$

6. Extent of Perceived Corruption Amongst Public Officials ........... $\quad 1^{2}$

7. Causal Chain of Types of Corruption According to the NGCS ... 157

8. "Percentage distribution enterprise [sic] reporting frequency of government procurement tenders being awarded in a clear and efficient manner"

\section{Tables}

1. Corruption and Access to the Political System ............................... 44

2. Development and Governance Indicators for Tanzania ............... 138

3. Tanzania Integrity Index Scorecard $2007 \quad$.......................................... 142

4. Mo Ibrahim Index of African Governance: Figures for Tanzania (2000-2007)

5. Analysis of Bribery in Tanzania by Purpose .................................. $\quad 156$

6. Concepts of Corruption and Political Order ………........................ 240

\section{Boxes}

1. MKUKUTA Cluster III-Goals and Targets for Governance and Accountability

2. Goals of NACSAP II 
Lucy Koechlin - 9789004252981

Downloaded from Brill.com04/26/2023 05:35:01AM via free access 


\section{ACKNOWLEDGEMENTS}

I would like to extend my heart-felt gratitude to all the persons in the construction industry and anti-corruption institutions of Tanzania. They showed great generosity and, sometimes, courage in sharing their time and expertise with me, and provided manifold insights into the institutional, professional and political context they are working in. I am only sorry that my research is of no greater immediate benefit to them. On an overarching level, my gratitude goes to all my friends far and near, to my colleagues across time- and landscapes, and to my family of African proportions, for endowing with me a sense of belonging and for accompanying me on my long and winding road with a unique mixture of stoic equanimity, great warmth and relentless sense of humour. Special thanks for rigorous critique and intellectual inspiration goes to Till Förster, and to Ursula Bürki, Denise Berger, Rebekka Gigon and Mirella Mahlstein for their patient support with proof-reading, formatting and compilation of tables. I owe all of the persons mentioned here a great intellectual, personal and practical debt. However, any corruptions of the text are solely my own responsibility. 
Lucy Koechlin - 9789004252981

Downloaded from Brill.com04/26/2023 05:35:01AM via free access 


\section{LIST OF ABBREVIATIONS}

$\begin{array}{ll}\text { A } & \text { Answer } \\ \text { AAT } & \text { Architects Association of Tanzania } \\ \text { ACET } & \text { Association of Civil Engineers } \\ \text { ACSPP } & \text { Anti-Corruption Strategy in Public Procurement } \\ \text { ADB } & \text { Asian Development Bank } \\ \text { AECT } & \text { Association of Electrical Contractors Tanzania } \\ \text { AEO } & \text { African Economic Outlook } \\ \text { AfDB } & \text { African Development Bank } \\ \text { AG-CS } & \text { Advisory Group on Civil Society and Aid Effectiveness } \\ \text { AGM } & \text { Annual General Meeting } \\ \text { approx. } & \text { approximately } \\ \text { AQSRB } & \text { Architects and Quantity Surveyors Registration Board } \\ \text { Art } & \text { Article } \\ \text { AusAID } & \text { Australian Government Overseas Aid Programme } \\ \text { BEST } & \text { Business Environment Strengthening for Tanzania } \\ \text { BPI } & \text { Bribe Payers Index } \\ \text { CCM } & \text { Chama Cha Mapinduza (Revolutionary Party) } \\ \text { CEO } & \text { Chief Executive Officer } \\ \text { CHRGG } & \text { Commission for Human Rights and Good Governance } \\ \text { CIP } & \text { Construction Industry Policy } \\ \text { CPAR } & \text { Country Procurement Assessment Report } \\ \text { CPIA } & \text { Country Policy and Institutional Assessment } \\ \text { CPI } & \text { Corruption Perceptions Index } \\ \text { CRB } & \text { Construction Registration Board } \\ \text { CRU } & \text { Conflict Research Unit } \\ \text { CSO } & \text { Civil Society Organisation } \\ \text { DAC } & \text { Development Assistance Committee } \\ \text { DANIDA } & \text { Danish International Development Agency } \\ \text { DFID } & \text { Department of International Development } \\ \text { DPP } & \text { Directorate of Public Prosecutions } \\ \text { EABI } & \text { Eastern Africa Bribery Index } \\ \text { Eng. } & \text { Engineer } \\ \text { EPA } & \text { External Payment Arrears } \\ \text { ERB } & \text { Engineers Registration Board } \\ \text { est. } & \text { established }\end{array}$


EU European Union

FACEIT Front Against Corrupt Elements in Tanzania

FIDIC International Federation of Consulting Engineers

ForDIA Forum for Democracy, Integrity and Accountability

F/Y Financial Year

GAO General Accounting Office

GAP Global Accountability Project

GDP Gross Domestic Product

GGCU Good Governance Coordination Unit

GNP Gross National Product

HDI Human Development Index

IACC International Anti-corruption Conference

IAP Implementation Action Plan

ICC International Chamber of Commerce

IET Institute of Engineers Tanzania

IFES International Foundation for Electoral Systems

IMF International Monetary Fund

IPTL Independent Power Tanzania Limited

LGA Local Government Authorities

LSE London School of Economics

MASP Multi-Annual Strategic Plan

MDA Ministries, Departments and Agencies

MID Ministry of Infrastructure Development

MKUKUTA Mkakati wa Kukuza Uchumi na Kupunguza Umaskini Tanzania (National Strategy for Growth and Poverty Reduction Tanzania)

MMDGPR Mid-term Millennium Development Goal Progress Report

MOU Memorandum of Understanding

MOW Ministry of Works

MP Member of Parliament

n/a not available

NACSAP National Anti-corruption Strategy and Action Programme

NCC National Construction Council

NEC National Executive Committee

NGCS National Governance and Corruption Survey (Tanzania)

NGO Non-governmental Organisation

ODA Official Development Assistance

OECD Organisation for Economic Co-operation and Development

OSHA Occupational Health and Safety Authorities

PACI Partnership Against Corruption Initiative 


\begin{tabular}{|c|c|}
\hline $\mathrm{p} / \mathrm{c}$ & per capita \\
\hline PCA & Prevention of Corruption Act \\
\hline PCCA & Prevention and Combating of Corruption Act \\
\hline PCB & Prevention of Corruption Bureau \\
\hline PCCB & Prevention and Combating of Corruption Bureau \\
\hline PM & Prime Minister \\
\hline PPA & Public Procurement Act \\
\hline PPAA & Public Procurement Appeals Authority \\
\hline PPRA & Public Procurement Regulatory Authority \\
\hline REPOA & Research on Poverty Alleviation \\
\hline SDC & Swiss Agency for Development and Cooperation \\
\hline SGACA & Framework for Strategic Governance and Corruption Analysis \\
\hline SIDA & Swedish International Development Cooperation Agency \\
\hline TACA & Tanzania Contractors Association \\
\hline TACECA & Tanzania Association of Civil Engineers \\
\hline TACO & Tanzania Association of Consultants \\
\hline TADREG & Tanzania Development Research Group \\
\hline TAICO & Tanzania Association of Informal Construction Workers \\
\hline TANU & Tanganyika National Union \\
\hline TI & Transparency International \\
\hline TIQS & Tanzania Association of Quantity Surveyors \\
\hline TIVEA & Tanzania Association of Valuers and Estate Agents \\
\hline TLS & Tanzania Law Association \\
\hline TOR & Terms of Reference \\
\hline Tsh & Tanzania Shillings \\
\hline TUCTA & Trade Union Congress of Tanzania \\
\hline $\mathrm{TZ}$ & Tanzania \\
\hline UN & United Nations \\
\hline UNCAC & United Nations Convention Against Corruption \\
\hline UNDP & United Nations Development Programme \\
\hline UNODC & United Nations Office on Drugs and Crime \\
\hline USD & United States Dollar \\
\hline $\mathrm{U}_{4}$ & Utstein Anti-Corruption Resource Centre \\
\hline Q & Question \\
\hline $\mathrm{v}$ & versus \\
\hline WB & World Bank \\
\hline
\end{tabular}

